\title{
HAZARD ASSESSMENT OF MICROCYSTINS FROM THE HOUSEHOLD'S DRINKING WATER
}

\author{
MoKoEnA, M. M. ${ }^{1 *}-$ MuKholA, M. S. ${ }^{1}-$ OKONKwo, O. J. ${ }^{2}$ \\ ${ }^{I}$ Department of Environmental Health, Tshwane University of Technology, Pretoria Campus, \\ Staatsartillery Road, P/Bag X680, Pretoria, 0001, Republic of South Africa \\ (phone: +27-12-382-4690; fax: +27-12-382-4690; email: mukholams@tut.ac.za)
}

${ }^{2}$ Department of Environmental, Water and Earth Sciences, Tshwane University of Technology, Arcadia Campus, 175 Nelson Mandela Drive, Arcadia, Pretoria, 0083, P/Bag X680, Pretoria, 0001, Republic of South Africa

(phone: +27-12-382-6545; fax: +27-12-382-6354; email: okonkwooj@tut.ac.za)

*Corresponding author:

email:mokoenamm1@tut.ac.za

(phone: +27-12-382-3544; fax: +27-12-382-5262)

(Received $27^{\text {th }}$ Nov 2015; accepted $23^{\text {rd }}$ Apr 2016)

\begin{abstract}
Cyanobacteria produce toxins which are hazardous to the health of people who are using water that is contaminated. The hazard quotient suggested by United States Environmental Protection Agency (USEPA) was used to assess the human health hazard of using contaminated water containers. There was no statistically significant difference $(\mathrm{P}=0.5511)$ in the level of microcystin between blooming and decaying seasons. Findings show that all treated water samples in the containers were below the $1.0 \mu \mathrm{g} / \mathrm{L}$ level, which underscore this important issue: drinking water from treated water in containers has no adverse health effect when compared to drinking water from non-treated water containers, whether used by adults or children. In conclusion, collecting and storing of either pre-treated or non-treated water using containers needs post-treatment before drinking.
\end{abstract}

Keywords: hazard quotient, microcystins modelling, cyanobacteria, water containers

\section{Introduction}

It is believed that recreational and occupational contact with contaminated water are the most common forms of exposure to cyanobacterial toxins in dams, rivers and marine water (Azevedo et al., 2008). In the reports of Hoffman (1976) and Duy et al. (2000) it was discovered that long-term exposure to low levels of cyanotoxins may also occur in areas which receive treated drinking water, as most of the conventional water treatment processes are ineffective in removing cyanotoxins (DWAF, 1996). Oberholster and Ashton (2008) reported that extra cellular toxin concentrations remained constant after flocculation and filtration in a conventional water treatment plant. Daly et al. (2007) evaluated the effect of chlorine on the cell integrity of toxic Microcystis aeruginosa. Flow cytometry determined live (viable) and dead (nonviable) Microcystis cells, and it was found to have a higher concentration of chlorine than what was suggested by Nicholson et al. (1994). The difference was that Daly et al. (2007) lysed the cell, whilst Nicholson et al. (1994) degraded the toxins directly. Tsuji et al. (1997) reported that chlorination and ozonation are effective means for the removal of microcystins. Nicholson et al. (1994) reported that a chlorine dose of $3 \mathrm{mg} / \mathrm{L}$ is effective in eliminating the presence of microcystins in drinking water if a residual of $0.5 \mathrm{mg} / \mathrm{L}$ is sustained for 30 minutes. This is because chlorine reacts with microcystin organic compounds to form trihalomethanes, which maybe also toxic and carcinogenic to 
humans (Muyodi, 2009). Chlorine bleach is inexpensive and readily available, in stores, for the public to purchase. All studies demonstrated that chlorine was effective in degrading microcystins in water (Tsuji et al., 1997 and Nicholson et al., 1994). The use of the correct concentration of bleach and the right $\mathrm{pH}$ has been proven to remove microcystins by up to $99 \%$ in drinking water (DWAF, 1996; Backer et al., 2008).

Toxic cyanobacteria are recognised as hazardous to human and animal health and assessments are carried out to determine environmental health problems (Ahmed et al., 2008). However, thorough investigation of human illnesses and deaths, following exposure to microcystins, are required. Some toxins produced by cyanobacteria are carcinogens. Non-carcinogenic microcystins have been the most widely investigated toxin group. The health risks posed by exposure to microcystins are difficult to quantify, since the actual exposure and the resulting effects have not been conclusively determined, especially in relation to humans (Chen et al., 2009). Microcystin exposure can also occur through contact with or ingestion of algal scums. Three potential sources of exposure to microcystins can be distinguished: direct contact of exposed parts of the body including ears, eyes, mouth and throat and the areas covered by a bathing suit (Pilotto et al., 1997), accidental swallowing (Turner et al., 1990) and inhalation of water spray (Chorus and Bartram, 1999). Fawell et al. (1994) studied the dose-exposure using pigs to determine the no-observed-adverse-effect-level (NOAEL), whilst Humpage and Falconer (2003) used mice to determine the LOAEL of microcystins. The recognised route of exposure of humans to microcystins is through water.

The most reported occurrence of human intoxication by microcystins was the outbreak of illness that occurred at a haemodialysis clinic in Caruaru, Pernambuca State, Brazil. Patients developed visual disturbances, nausea, vomiting and muscle weakness; some patients developed acute liver failure (Azevedo et al., 2002). The study outcome was confirmed by comparing the human symptoms with those of animals that were studied and led researchers to conclude that humans were exposed specifically to microcystins LR, YR and AR. A study conducted by Ding et al. (2006) demonstrated that microcystins cause stomach and intestinal inflammation, liver cancer and disease of the spleen in humans who drink contaminated water. Microcystins have been linked to promoting tumour development and have clearly demonstrated having an effect on the liver and the colon (Falconer, 2005). Unfortunately, there is no confirmation of microcystins exhibiting carcinogenic tendencies, as they would need very high intraperitoneal doses of toxin (Falconer, 2005; Ito et al., 1997). The USEPA (2005) reported a need to generate sufficient epidemiological data to be able to estimate the risks. Animals are generally used in toxicity studies and the results extrapolated to humans.

Masango et al. (2010) reported an increase of microcystins from an average of 49.41 $\mathrm{mg} \mathrm{L}^{-1}$ in February during summer blooming of the cyanobacteria, to $103.16 \mathrm{mg} \mathrm{L}^{-1}$ in June in the dam water found in the Kruger National Park. This increase in microcystin concentration was the result of the dying-off of cells in winter. Most research studies have been conducted on animals (Oberholster et al., 2005; Masongo et al., 2010), but there are reported cases of human health effects (Jochimsen et al., 1998) caused by microcystin. Nobre et al. (1999) studied the physiopathologic effects of a rat kidney perfused with a microcystin-LR solution and Masango et al. (2010) reported the death of mice within one hour after injecting them with water samples from a dam following the blooming of cyanobacteria, during a follow-up study resulting from the death of wildlife in the Kruger National Park. It was shown that the death of wildlife, in the 
study area, was due to toxic Microcystis. Willen et al. (2011) studied the deaths of wild and domestic animals around the Rift Valley in Kenya and reported traces of microcystins produced by Microcystis aeruginosa as the dominant species. The toxins were found to exceed $1 \mu \mathrm{g} \mathrm{L}^{-1}$ levels. Moreno et al. (2004) compared the effects of microcystins between humans and animals. In this study, they assessed the degradation of microcystins in human gastrointestinal tract before absorption and found alterations in gastric conditions by all the toxin assays studied. Microcystin-RR was the most prevalent toxin, the degradation of which ranged between 49 and 64\%, whilst for others, such as Microcystin-YR and-LR, degradation percentages were around $30 \%$.

Human health risk characterisation is defined as an integration of the findings from the exposure to microcystins and the consequent effects. The carcinogenesis guideline to drinking water is not yet conclusive, however, the risk assessment procedure was adopted from the non-carcinogenic chemicals and there was a derivation of the drinking water Guideline Value for microcystins. Falconer (2005) reported that a preferential procedure uses epidemiological data from human exposure and poisoning from microcystins in drinking water. In their study, two doses were used to determine the higher and lower levels which would not have any effects on animals or humans if administered. The higher dose with no effects on animals is called the 'No Observed Adverse Effect Level' (NOAEL) and the lowest dose that causes minimum effect is called the 'Lowest Observed Adverse Effect Level' (LOAEL). The World Health Organization uses this procedure of toxin doses to calculate the acceptable guideline of microcystins in drinking water. The guideline is based on the body mass of the animals, when compared to reported different doses from other animal studies (TDI), and the total daily dose intake which is administered to the animals for up to 14 weeks. The total daily intake (TDI) equation was used to estimate doses for drinking water quality assessment (Codd, 2005). In order to derive to TDI, the LOAEL or NOAEL was used and divided by the appropriate safety or uncertainty factors (WHO, 2006).

In 1998, the World Health Organization (WHO) provided many countries with the provisional guideline of $1 \mu \mathrm{g} \mathrm{L}^{-1}$ in drinking water. It is documented as a provisional guideline because it only covers the Microcystin-LR and not all cyanotoxins, as there is very little data available about other toxins. Some of these countries, including Brazil, New Zealand, Japan and Spain, recently directly adopted the WHO provisional guideline for microcystin-LR for drinking water. Burch and Thomas (1998) compared the international guidelines for microcystins-LR. South Africa uses the range of 0-0.8 $\mu \mathrm{g} \mathrm{L}^{-1}$ (DWAF, 1996), SANA 241 uses the WHO guideline value of $1 \mu \mathrm{g} \mathrm{L}^{-1}$, while other countries, such as Australia and Canada, have developed guidelines of $1.3 \mu \mathrm{g} \mathrm{L}^{-1}$ and $1.5 \mu \mathrm{g} \mathrm{L}^{-1}$ respectively, using a range above the recommended level of the WHO.

Microcystin in one of the toxins produced by the cyanobacteria and mostly found in drinking water. Toxins are grouped into two, carcinogenic and non-carcinogenic toxins, and are reported to cause either acute or chronic health effects if ingested. Microcystin is still grouped under the non-carcinogenic group as there is no study, as of yet, to prove if it causes cancer only suggestions it may advance the development of cancer. Therefore, in order to determine whether microcystin can cause the adverse health effect of humans, if found in drinking water, the hazard quotient model should be applied. Human health risk assessments of microcystins were simulated using recreational water and studies conducted from animals, as there no human health epidemiological studies using microcystins as indicators in drinking water containers. This is because there is limited dose data which can be used to calculate the hazard quotient. The use of water 
containers as a water storage facility is a tertiary water point in most rural areas in developing countries such as South Africa. Therefore the adverse health effects of stored water containers at household levels is not yet understood.

The present study assesses the human health hazard modelling of microcystins in drinking water containers. This was determined by assessing the quality of water used for drinking purposes, which were grouped together by their respective water sources and water containers stored in households. Microcystin concentration was determined in both treated and non-treated water samples and this data were used to calculate the associated health hazard.

\section{Materials and methods}

\section{Study area}

The study was conducted in the communities situated around Hartbeespoort Dam, in the North West Province, South Africa. Four different water sources (communal tap, tank supply, groundwater and Rand-water), used by community members, were assessed at household level. The Rand Water Board supply water from the Vaal Dam, directly to people in the study area of Hartbeespoort Dam, through house connections. Water from Hartbeespoort Dam water, was treated by Schoemansville Water Treatment and supplied by trucks to the area through communal taps and tanks supplied to communities. Ground water was provided via private boreholes, which individuals drilled themselves in their yards.

\section{Water samples collection}

Water samples were collected from the water containers of all the participating households, as well as from their respective water sources. Water samples were collected at different seasons, namely: blooming season (spring and summer) and decaying season (autumn and winter) between 2012 and 2013. The samples were collected using sterile $500 \mathrm{ml}$ Whirl Paks. These samples were immediately stored in cooler boxes at less than $4^{\circ} \mathrm{C}$ (Chorus and Bartam, 1999) and transported to the laboratory for analysis within 24 hours of sampling. Sodium hypochlorite was used from $40 \%$ of the selected households as the point of water treatment usage. During the collection of water samples, care was taken to ask the household member if water was treated with bleach $(\mathrm{NaOCl})$ and at what time it was treated. This was done to assess whether water treatment by bleach at household level was done 30 minutes prior to usage, as this is as an acceptable time lapse for consumption of the water. Immediately, in the laboratory, two drops of Lugol's solution were added to the water samples and they were kept in a black plastic bag to prevent exposure to sunlight (Funari and Testai, 2008). Immediately on arrival in the laboratory, $2 \mathrm{ml}$ of the water sample was decanted into an Eppendorf tube and frozen at $80^{\circ} \mathrm{C}$ until further analysis of the toxins was necessary. The method of analysing microcystins is described fully below.

\section{Microcystins analysis}

Analyses of microcystins were performed using the Abraxis Microcystins-ADDA ELISA kit (Microtiter plate) from ToxSolutions kit in South Africa, following the Abraxis procedure (PN.520011) that has six standard solutions and one control. After the mixing, washing and incubation of the microcystins solution, the plate was placed 
into a micro-reader to read the results. Data was captured on Microsoft Excel Office and statistical analysis was done using Stat V-10.

\section{Microcystin human health hazard assessment model}

The standard human health risk assessment approach incorporates two steps: risk assessment and risk characterisation. Risk assessment methodology incorporates the following steps: hazard identifying, exposure assessment, toxicity assessment and quantifying risk and hazard.

\section{Hazard identifying}

In carrying out the hazard identification and dose-response assessment of microcystins in drinking water, studies identified the level of toxins in drinking water. Many studies have been conducted in order to relate human and animal health problems to the presence of microcystins in water; microcystins were analysed as indicators of contamination in drinking water. The study assesses the water quality used for drinking purposes for two seasons: the blooming and decaying seasons. Cases of microcystins health problems have being reported worldwide. From the studies conducted using animals, the adverse effects of microcystins were determined using both NOAEL and LOAEL. Hazard identification, microcystin hazard analysis, was started with the estimation of the total daily intake (TDI).

\section{Exposure assessment}

It was expected for household members to be exposed to microcystins via the oral route, through the ingestion of contaminated container water during their life time. The safe doses of microcystins in the drinking water were to be determined and used to estimate the daily dose intake. The toxicological data was used to calculate a Tolerable Daily Intake.

For non-carcinogenic substances, the dose can be calculated using the intake equation below:

$$
T D I=\frac{M C^{*} I R^{*} E F^{*} E D}{B W^{*} A T}
$$

$T D I=$ tolerable daily intake, $M C=$ microcystin concentration, $I R=$ contact rate (L/day), $E F=$ exposure frequency (in days), $E D=$ exposure duration (in years), $B W=$ Body Weight (in $\mathrm{kg}$ ) and AT = average time (in days).

For the exposure of the microcystins contamination in drinking water, the HQ is based on the oral exposure to microcystins, considering the body weight of $70 \mathrm{~kg}$ for adults and $15 \mathrm{~kg}$ for children, at daily water ingestion volumes of approximately $2 \mathrm{~L} /$ day see Table 1. For the microcystins concentration, the oral $\mathrm{LD}_{50}$ or NOEAL of the either pig or mice were considered. 
Table 1. Defines lists the symbols used in equation 1 and the study concentration used during TDI calculation.

\begin{tabular}{l|l|l}
\hline Parameter & Definition & Resident \\
\hline IR & Contact rate (in L/day) & 2L/day drinking water \\
\hline EF & Exposure frequency (in days per year) & 350 days/year \\
\hline ED & Exposure duration (in years) & Actual event duration or 30 years if chronic \\
\hline BW & Body weight (in kg) & $70 \mathrm{~kg}$ (adult), 15 kg (child) \\
\hline AT & $\begin{array}{l}\text { Period over which exposure is averaged (in } \\
\text { days) }\end{array}$ & $\begin{array}{l}\text { Actual event duration if not carcinogenic, or 365 } \\
\text { day/years * 70 years if carcinogenic. }\end{array}$ \\
\hline MC & $\begin{array}{l}\text { Exposure point concentration } \\
\text { Average concentration of contaminant } \\
\text { (Microcystins) on exposure (in mg/L if in water) } \\
\mu \mathrm{g} / \mathrm{L} . \quad\end{array}$ \\
\hline
\end{tabular}

\section{Toxicity assessment}

It is also appropriate to consider the establishment of a reference dose (RfD). The $\mathrm{RfD}$ is an estimate of the amount of substance in drinking water, normally expressed in a body weight, which can be ingested in a period of 24 hours. Drinking water samples were assessed for the concentration of microcystins during blooming and decaying seasons. The concentrations of the microcystins were relative to the exposure of people to the water during their lifetime.

$$
R f D=\frac{N O E A L o r L O E A L}{U F}
$$

$R f D=$ reference dose, NOEAL $=$ no-observed-adverse-effect level, LOEAL $=$ lowestobserved-adverse-effect level and UF = uncertain factor

\section{Quantifying risk and hazard}

The determination of the microcystins non-carcinogenic risk assessment in drinking water was carried out according to the exposure pathways of contaminants recommended by the United States Environmental Protection Agency (USEPA).

$$
H Q=\frac{T D I}{R f D}
$$

$H Q=$ hazard quotient,$T D I=$ tolerable daily intake and $R f D=$ reference dose

Interpreting the results of non-carcinogenic risk assessment:

When HQ is greater than 1 there are further steps to be employed for adequate risk assessment. These steps (options) include: sources control, deed restrictions, institutional controls and remediation.

\section{Ethics}

The proposed project and tools to be used were submitted to the Tshwane University of Technology Ethics Committee and permission was obtained. The study involved 
interviewing household members and sample collection at their households, however before data collection could begin adult members were asked to sign a consent form should they wish to participate. The household members' involvement was entirely voluntary in nature. The water samples were analysed for the presence of microcystins and other water quality parameters.

\section{Results and discussion}

Communities around the Hartbeespoort Dam use different water sources which are likely to be contaminated by the toxins (Microcystins) produced by the cyanobacteria. Microcystins are produced by Microcystis Aeruginosa during blooming and decaying seasons (Pawlik-Skowronska et al., 2008; Chaturvedi et al, 2015). These microcystins can survive for, at least, 21 days under good conditions such as warm temperature, good nutrients and calm wind (Backer et al., 2008).

\section{Hazard identification in water sources}

The dam was the main source supplying water to different water points used for drinking purposes. Microcystins were found in almost all water sources used in the area, but especially in the Hartbeespoort Dam water, which was also reported by Oberholster and Ashton (2008). Data of water samples from different water sources are shown in Table 2. It was assumed there was a direct link between the surface water (Hartbeespoort dam) to the communal tap and communal tank water after exposure to the treatment plant and direct contamination of the ground water that was drilled a few kilometres away from the dam (Hiscock and Grischek, 2002). It was further assumed that water supplied by Rand Water would have no association with the surface water in the study area as this water was supplied from Lesotho through the Vaal Dam Water Treatment. The World Health Organization (WHO) suggests a provisional microcystins guideline, derived from the study of Microcystin-LR. Therefore, for the purpose of this study, the same microcystin guideline $\left(1 \mu \mathrm{g} \mathrm{L}^{-1}\right)$ in drinking water was applied in the results discussion section.

Microcystins data showed that dam water was significantly $(\mathrm{P}=0.9888)$ more contaminated with microcystins when compared to the other four water sources used (Table 2). The four water sources (Groundwater, Rand-water, Tank water and Tap water), showed less contamination of microcystins than that of the dam water. Although the microcystins contamination median was below the acceptable limits $\left(1 \mu \mathrm{g} \mathrm{L}^{-1}\right)$, there were still some water samples that had more than the acceptable value of microcystins concentration given the order of contamination shown, i.e. ground water $>$ Rand Water $>$ tank water $>$ tap water. Following the treatment of water by the treatment plant, there was a decrease, by half, in the microcystins (to $2.3 \mu \mathrm{g} \mathrm{L}^{-1}$ of tap water) during the blooming seasons. The removal of microcystins was not complete in the water treatment plant as toxins were also found in communal taps connected to the plant. Hence, there was difference in microcystins content between the decaying and the blooming seasons. In the decaying seasons, there was less than $1 \mu \mathrm{g} \mathrm{L} \mathrm{L}^{-1}$ in the tap water sample when compared to $5.0 \mu \mathrm{g} \mathrm{L}^{-1}$ in the dam water sample. The high level of microcystins in tap and tank waters during blooming season's treatments could be due to the fact that the treatment was unable to remove all the toxins produced (DWAF, 1996). In summer, the cyanobacteria cells from scums or mats resulted from the blooming of the cells in the surface water. The blooming of cyanobacteria is as a result of sufficient nutrients, calm 
wind, heavy rain and warm temperatures. Toxins are produced by the cells due to stress and overcrowding (Neilan et al., 2013). Therefore, water becomes highly turbid and it becomes a challenge for water treatment to remove, completely, all unwanted particles, including cells and toxins.

Table 2. Mean concentration $\left(\mu \mathrm{g} L^{-1}\right)$ of microcystins in different water points.

\begin{tabular}{|c|c|c|c|}
\hline & $\begin{array}{l}\text { Blooming - Microcystins } \\
\text { non treated }\end{array}$ & $\begin{array}{l}\text { Decaying - Microcystins } \\
\text { non treated }\end{array}$ & $\begin{array}{lll}\text { Microcystin } & \text { guideline } \\
\text { Drinking water } & \text { (WHO) }\end{array}$ \\
\hline $\begin{array}{l}\text { Dam Water } \\
\text { Min-Max } \\
\text { Mean } \pm \text { SD }\end{array}$ & $\begin{array}{l}(0.00010-8.6) \\
4.3 \pm 4.9\end{array}$ & $\begin{array}{l}(3.5-6.2) \\
5.0 \pm 1.4\end{array}$ & \multirow{5}{*}{$1.0 \mu \mathrm{g} \mathrm{L}^{-1}$} \\
\hline $\begin{array}{l}\text { Groundwater } \\
\text { Min-Max } \\
\text { Mean } \pm \text { SD }\end{array}$ & $\begin{array}{l}\text { ND } \\
\text { ND }\end{array}$ & $\begin{array}{l}(0.4-0.4) \\
0\end{array}$ & \\
\hline $\begin{array}{l}\text { Rand-Water } \\
\text { Min-Max } \\
\text { Mean } \pm \text { SD }\end{array}$ & $\begin{array}{l}\text { ND } \\
\text { ND }\end{array}$ & $\begin{array}{l}\text { ND } \\
\text { ND }\end{array}$ & \\
\hline $\begin{array}{l}\text { Tank Water } \\
\text { Min-Max } \\
\text { Mean } \pm \text { SD }\end{array}$ & $\begin{array}{l}\text { ND } \\
\text { ND }\end{array}$ & $\begin{array}{l}(0.00010-4.2) \\
1.4 \pm 2.0\end{array}$ & \\
\hline $\begin{array}{l}\text { Tap Water } \\
\text { Min-Max } \\
\text { Mean } \pm \text { SD }\end{array}$ & $\begin{array}{l}(0.00010-5.2) \\
2.3 \pm 1.9\end{array}$ & $\begin{array}{l}(0.00010-1.3) \\
0.6 \pm 0.5\end{array}$ & \\
\hline
\end{tabular}

$\mathrm{ND}=$ no data to be presented in that group

During the decaying seasons, the microcystin level was significantly $(\mathrm{P}<0.001)$ reduced between dam water and tap water, from 5.0 to $0.6 \mu \mathrm{g} \mathrm{L}^{-1}$. This could be due to the effect of the reduction in the turbidity levels from 9.5 NTU in the blooming seasons to $7.4 \mathrm{NTU}$ in the decaying seasons, thus enabling the water treatment plant to treat the cyanobacterial cells and toxins at the lower level turbidity. A decrease in the levels of microcystin was observed in the communal tap water samples between blooming $(2.3$ $\left.\mu \mathrm{g} \mathrm{L}^{-1}\right)$ and decaying seasons $\left(0.6 \mu \mathrm{g} \mathrm{L}^{-1}\right)$. The dam and tap waters' data confirmed that most water treatment plants are unable to treat microcystins completely, as reported (Daly et al., 2007), especially during the blooming season. Groundwater and Rand Water samples did not have microcystins that were detected in both seasons. There was a significant difference $(\mathrm{P}=0.4174)$ in the water sources' quality between the blooming and decaying seasons.

\section{Hazard identification in water containers}

Water samples from the above mentioned sources were collected and stored using plastic containers (Sobsey, 2002) by the community members, who use it for drinking and domestic purposes. Water storage containers sizes differed depending on the needs of the household members and settlement types; in a private area such as Meerhof, most people used 10L light penetrating plastic containers to store drinking water, with only a few using 2000L tanks. In the informal settlements, such as Kosmos and Zandfontein, more than $95 \%$ households used $20 \mathrm{~L}$ or $25 \mathrm{~L}$ light penetrating and opaque plastic containers. People in the RDP area of Refense also use 20L or 25L light penetrating containers, but mostly 200L opaque plastic containers, because they get water from the tanker supplied by truck. Data of the water samples from these containers are shown in Table 3, which was grouped according to the water sources (where the water was 
collected). The data were further grouped according to the seasons. As there was no group of people using the dam water directly for domestic purposes, there was no result to be discussed.

Point-of-use water treatment was practiced in 29 (39\%) of the households that participated in the study and these were strategically selected. In the water containers group, no significant difference $(\mathrm{P}=0.9999)$ was found between the levels of microcystins in either treated or non-treated water $(\mathrm{P}=0.8040)$, either in the blooming or the decaying seasons $(\mathrm{P}=0.6141)$. Microcystins ranged from $95 \%$ confidence interval $(0.034$ to 0.187$)$ and $(0.0536$ to 0.4058$)$ for treated water samples of the blooming seasons and decaying seasons respectively $(\mathrm{P}=0.2758)$, while $95 \%$ confidence interval $(0.4595$ to 1.6662$)$ and $(0.6402$ to 1.6755$)$ for non-treated water in the blooming and decaying seasons $(\mathrm{P}=0.8215)$. There was a significant increase $(\mathrm{P}=$ 0.0028 ) in the microcystins concentration from treated (with bleach) to non-treated water samples within the confidence intervals $(-0.02842$ to 0.1588$)$ and $(0.4807$ to 1.7237) in the blooming season. The same patterns were also observed in the decaying season, where there was a significant increase $(P=0.0012)$ in the microcystins concentration from treated with bleach to non-treated water samples within confidence intervals (-0.05364 to 0.4058$)$ and (0.7847 to 1.9712$)$ in the decaying season.

\section{Blooming season water container quality}

Drinking water container qualities used at household levels were compared using microcystins as an indicator of water contamination and the effect of bleach in its treatment. The mean level of microcystins of non-treated Rand Water containers was $0.21 \mu \mathrm{g} \mathrm{L}^{-1}$ less than the acceptable limit. Water from the Rand Water source did not contain microcystins, however, the containers used to store the water did have microcystins in them. This could be as a result of using the same containers to collect water from other water sources at a time when water was not available at the settlement.

Table 3. Mean concentration $\left(\mu \mathrm{g}^{-1}\right)$ of microcystin in water containers at household level.

\begin{tabular}{l|l|l|l|l}
\hline & $\begin{array}{l}\text { Blooming season - } \\
\text { (Microcystin) } \\
\text { Household water } \\
\text { treatment }\end{array}$ & $\begin{array}{l}\text { Blooming season- } \\
\text { (Microcystin) } \\
\text { Household non water } \\
\text { treatment }\end{array}$ & $\begin{array}{l}\text { Decaying season - } \\
\text { (Microcystin) } \\
\text { Household water } \\
\text { treatment }\end{array}$ & $\begin{array}{l}\text { Decaying season- } \\
\text { (Microcystin) } \\
\text { Household non } \\
\text { water treatment }\end{array}$ \\
\hline $\begin{array}{l}\text { Groundwater } \\
\text { Min-Max } \\
\text { Mean } \pm \text { SD }\end{array}$ & ND ND & ND & ND & $(0.00010-1.91)$ \\
\hline Rand-Water & ND & ND & $0.5 \pm 0.81$ \\
$\begin{array}{l}\text { Min-Max } \\
\text { Mean } \pm \text { SD }\end{array}$ & ND & $(0.00010-1.26)$ & ND & $(0.00010-4.42)$ \\
\hline $\begin{array}{l}\text { Tank Water } \\
\text { Min-Max }\end{array}$ & $(0.00010-1.18)$ & $(0.00010-4.33)$ & $(0.00010-1.80)$ & $1.5 \pm 2.09$ \\
Mean \pm SD & $0.08 \pm 0.28$ & $1.16 \pm 1.56$ & $0.14 \pm 0.47$ & $(0.00010-3.26)$ \\
\hline $\begin{array}{l}\text { Tap Water } \\
\text { Min-Max }\end{array}$ & $(0.00010-0.22)$ & $(0.00001-4.37)$ & $(0.00010-1.89)$ & $(0.00010-3.36)$ \\
Mean \pm SD & $0.032 \pm 0.083$ & $1.75 \pm 1.98$ & $0.27 \pm 0.71$ & $1.23 \pm 1.50$ \\
\hline
\end{tabular}

$\mathrm{ND}=$ there were no data to be presented in that group

Residents also reported they stored water for long periods of time, as they were not sure when the water would be turned-off and when their taps would be turned on again. 
Other households reported that they live in a lower water pressure area, therefore they often receive water only in the evening when demands are not too high, forcing them to store water in their containers. Microcystins in treated water containers from tanks were observed to be as high as $1.18 \mu \mathrm{g} \mathrm{L}^{-1}$, which is greater than the acceptable limit, but a mean concentration of $0.08 \mu \mathrm{g} \mathrm{L}^{-1}$, which is below the acceptable level, was observed. However, microcystins levels in non-treated water containers collected from the tank water were above the acceptable limits of $4.33 \mu \mathrm{g} \mathrm{L}^{-1}$ and $1.16 \mu \mathrm{g} \mathrm{L}^{-1}$ for maximum and mean concentration levels respectively. The microcystins concentration of non-treated water was four times the concentration of the treated water using bleach. This shows that the $\mathrm{NaOCl}$ was effective in treating water containers to an acceptable level. Microcystins in the treated water containers from taps were observed to be at a maximum concentration level of $\left(0.22 \mu \mathrm{g} \mathrm{L}^{-1}\right)$, which is within the acceptable limit although a mean concentration of $0.032 \mu \mathrm{g} \mathrm{L}^{-1}$, which is below the acceptable level, was observed. However, microcystins levels in non-treated water containers collected from the same tank were above the acceptable limit of $4.37 \mu \mathrm{g} \mathrm{L}^{-1}$ and $1.75 \mu \mathrm{g} \mathrm{L}^{-1}$ for maximum and mean concentration levels respectively. The same pattern of microcystin treatment was observed in the water containers from the tap as that from the tank. The point-of-use water treatment practices had a significant decrease $(\mathrm{P}=0.0028)$ of microcystins in water containers when compared to those of untreated water.

\section{Decaying season water container quality}

The decrease of microcystins in water containers was also observed during the decaying season. The findings show that microcystins $\left(0.14 \mu \mathrm{g} \mathrm{L}^{-1}\right)$ were below the acceptable limit of $1 \mu \mathrm{g} \mathrm{L} \mathrm{L}^{-1}$, when treating water with bleach, at a maximum concentration of $1.80 \mu \mathrm{g} \mathrm{L}^{-1}$ in the tank water. However, from the non-treated tank water, the minimum microcystin concentrations were $1.26 \mu \mathrm{g} \mathrm{L}^{-1}$ and the maximum was $3.26 \mu \mathrm{g} \mathrm{L}^{-1}$. The level of microcystins in treated water containers decreased more than three times compared to the non-treated ones. The microcystin concentrations in the treated water containers were observed to average at $0.27 \mu \mathrm{g} \mathrm{L}^{-1}$ and pealed at $1.89 \mu \mathrm{g}$ $\mathrm{L}^{-1}$. Those who did not treat their water kept in household containers were exposed to microcystins, with a mean concentration of $1.23 \mu \mathrm{g} \mathrm{L}^{-1}$ and a maximum concentration of $3.36 \mu \mathrm{g} \mathrm{L}^{-1}$. Groundwater was used in the study area as an alternate water source since most of the wells available were privately owned. There were a few people who stored groundwater in containers for domestic use. Data were collected during decaying season and not all participants treated their groundwater with bleach. Data presented in Table 3 shows that the mean microcystin concentration of groundwater was $0.5 \mu \mathrm{g} \mathrm{L}^{-1}$ and a maximum concentration of $1.91 \mu \mathrm{g} \mathrm{\textrm {L } ^ { - 1 }}$. Microcystins concentration was also observed in Rand-Water water containers. The findings show that microcystins were detected from water containers at mean a concentration of $0.5 \mu \mathrm{g} \mathrm{L}^{-1}$, which was less than the acceptable level, however the results also revealed a maximum concentration of $1.91 \mu \mathrm{g} \mathrm{L}^{-1}$. This level of contamination by microcystins could have been due to the use of the same containers to collect water from other sources. Improper hygiene practices could also be one of the reasons for major water deterioration.

\section{Discussion of water container quality in seasons}

It was observed that water containers from all sources grouped together, shared no statistically significant difference $(\mathrm{P}=0.5511)$ from blooming and decaying seasons. 
Tap and tank water microcystins were further compared during these seasons; there was no significant difference $(\mathrm{P}=0.5379)$ in water container contamination by microcystins in non-treated water from tap or tank. The microcystins exposure in water containers was similar (1.16 and 1.26; 1.75 and 1.23$)$ for tap and tank respectively. This finding shows that water container contamination and the level of microcystins in storage containers were not determined by external factors such as favourable conditions, rain fall, low or high temperature. It can, therefore, be concluded that the types of containers used, such as light penetrating containers as reported by Fosso-Kankue et al. (2008), contribute to water quality deterioration. Jagals (2006) and Gundry (2004) also reported that further deterioration of water containers is due to the access to water by children and domestic animals, use of scooping vessels as well as time of storing water. However, microcystins were significantly reduced $(\mathrm{P}<0.0001)$ in all water treated by bleach at the point of use when compared to non-treated water containers.

\section{Microcystins human health hazard assessment models}

There were 504 participants in the study, of which 55 (11\%) were children less than 5 years. The chemical assessment of non-carcinogen health adverse health effects using hazard quotient (HQ) was applied to determine the microcystins human health hazard. If the HQ between the two is greater than 1, people or animals would be at high risk; this means that $50 \%$ of the population using the substance with the contamination of the toxins will experience sub-lethal effects (Sánchez-Bayo et al., 2011). The hazard quotient (HQ) for children and adults through exposure of drinking water containers (DWC) to microcystins is shown in Figures 1 and 2 (Figure 1 shows the HQs of adults and children during the blooming season and Figure 2 shows the HQs during the decaying season). The figures further grouped the HQ results of DWC of water treated or non-treated, using bleach. The HQs through treated DWC to microcystins by children and adults in the blooming season were less than 1.0 for all DWC from the tap and tank sources. There was no data collected for water treated with bleach for the groundwater and Rand Water groups. HQs through non-treated DWC to microcystins by children and adults in the blooming season were greater than 1.0 for all DWC from the tap and tank sources. The groundwater and Rand Water's HQs through non-treated were less than 1.0 for both children and adults (Figure 1). HQs through non-treated DWC by children in the study area, had the maximum HQs of 5.7 and 3.8 at the tap water and tank water, respectively. Also, non-treated DWC for the adults' HQs were 8.20 and 5.46 for tap water and tank water, respectively.

Generally, the HQs through treated DWC to microcystins of the children and adults in the study area were less than 1.0 for all water sources (tap and tank) that were treated at point of use, while the HQs through non-treated DWC to microcystins by children and adults were above 1.0; this shows that non-treated water posed adverse health effects. It is reported by the USEPA risk assessment guidelines, with a hazard quotient greater than 1.0, that the probability for adverse health effects associated with exposure to such toxins is high. Only non-treated water containers produced hazard quotients of greater than 1.0 for adults and children. This shows the adverse health effect to people drinking water from containers can be experienced from collected and stored nontreated water. The toxin hazard can however be reduced to acceptable levels if water is treated using bleach at point of use. 


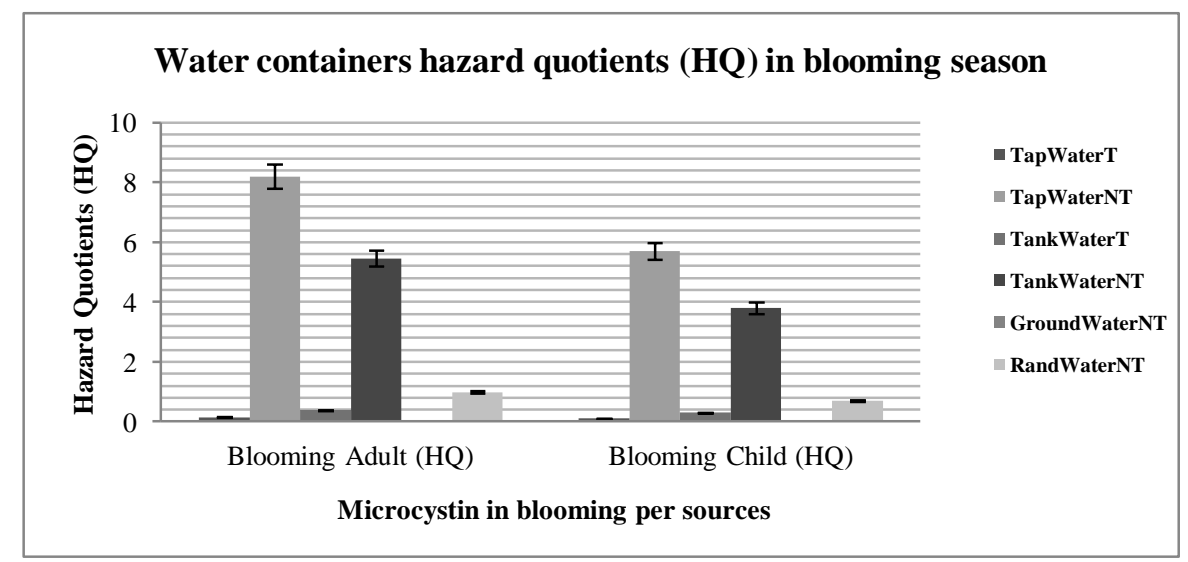

Figure 1. Hazard quotient $(H Q)$ from exposure to microcystins by resident children and adults via water containers

Figure 2 shows the HQs of decaying seasons grouped by the water sources used in the household for adults and children. All water container data was further grouped into treated or non-treated using bleach.

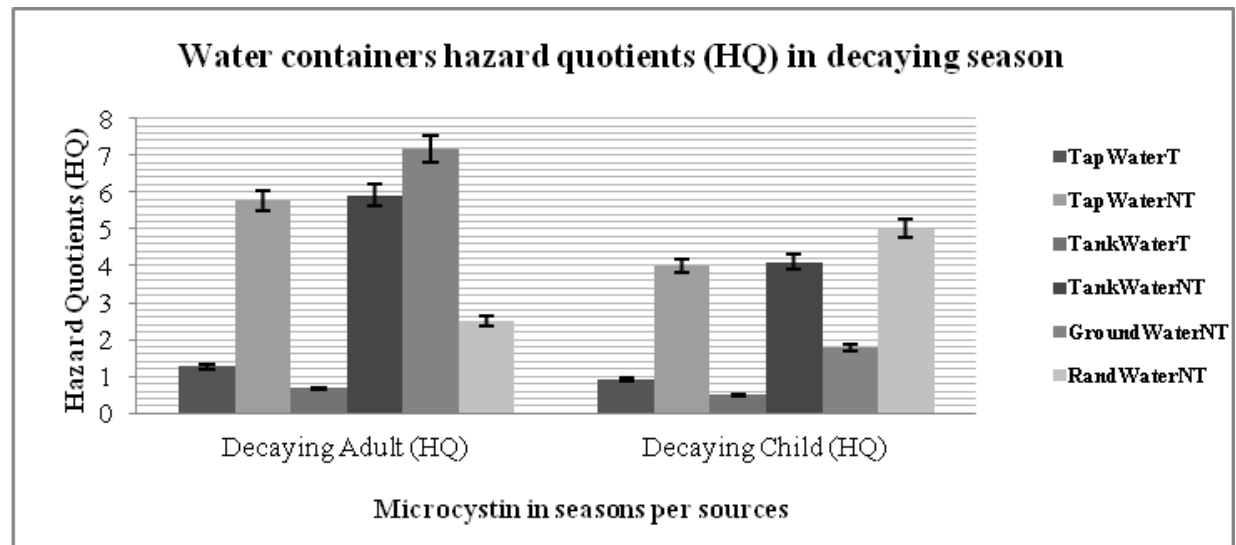

Figure 2. Hazard quotient (HQ) from exposure to microcystin by resident children and adults via water containers

The HQs through treated DWC to microcystins for adults in decaying season were less than 1.0 for the tank sources and greater than 1.0 for tap sources, which was 1.27. However, the HQs through treated DWC to microcystins for children in decaying season were all less than 1.0 for both tap and tank water sources (Figure 2). A close look at the non-treated HQs through DWC to microcystins for children and adults in decaying season shows HQ greater than 1.0 for all water sources (tap, tank, groundwater and Rand Water). In adults, HQs were 5.76, 5.91, 7.18 and 2.51 for tap, tank, groundwater and Rand Water respectively. Similarly the HQs through DWC for the children were 4, 4.1, 1.8 and 5 for tap, tank, groundwater and Rand Water respectively.

Hypothetically speaking, the decaying season should have no toxins produced as it was believed that all cyanobacteria cells were removed during water treatment and, as there was lower turbidity, chlorination contact time with microcystins should be 
sufficient to degrade it (Zong et al., 2015), however, stored water containers recontamination and poor hygiene practices resulted in the growth of biofilm inside the containers (Fosso-Kankue et al., 2008). During dying and decaying, cells release toxins (Gélinas et al., 2014). This could be supported by the data (Figure 2) on the level of HQs non-treated water containers that were greater than 1.0 in all sources used. Furthermore, water container treatment using bleach was shown to be effective in treating microcystin. During the blooming and decaying seasons (Figures 1 and 2) of treated DWC, HQs data were all below 1.0, the fact that water was not free of toxins could be because some of cyanobacteria were resistant to chlorination or to the poor conditions, such as pH concentration and enough contact time (Zong et al., 2015). This could indicate that the hazard level of microcystins that people are exposed to may have no adverse effect on their health, while all HQs data of non-treated DWC above 1.0 could have possible adverse health effects.

The continuous ingestion of non-treated DWCs that are collected and stored by adults and children in the study area makes them susceptible to health hazards associated with exposure to microcystins. Such health symptoms manifest in two ways: exposure to low levels of microcystins for a long time could result in tumour promotion and kidney and liver problems, while exposure to a high concentration of microcystins for a short period of time could result in gastroenteritis disorder, respiratory tract infection, diarrhoea, vomiting, nausea, etc.

\section{Conclusion}

The presence of microcystins was shown in different water sources used by residents in the area, where such water was collected for drinking purposes. It had a direct link with the Hartbeespoort Dam water irrespective of the treatment process used, this included the tap and tank waters that were pre-treated before being supplied through communal taps or tankers and the groundwater that had an aquifer as the treatment process of most pathogen microorganisms. The presence of microcystins in water containers was proven to be above the acceptable limits. This was shown to be hazardous and, if exposed to the users as was done in most water containers, could have short or long term effects if there was continued use of the water in this state. The exposure to high concentration of MC results in gastroenteritis health problems (diarrhoea, vomiting, nausea and stomach pain) (Brookes, et al., 2008) and low concentration reportedly promoted tumour development and kidney problems (de Figueiredo et al., 2004). Water treatment at the point of use should always be practiced, as it was observed that the adverse health effect level was reached from all the nontreated water groups in both seasons. Furthermore, proper water treatment using bleach and educational campaigns by DWA and the Department of Health is a requirement in all areas that are exposed to cyanobacteria contaminated water. Further studies are needed on trihalomethanes and dissolved organic compounds, since chlorine reacts with microcystins to form trihalomethanes.

Acknowledgements. The authors acknowledge the following: The THRIP programme of the NRF for financial support and Tshwane University of Technology for providing study infrastructure, The Hartbeespoort Inhabitant Forum for assistance, Rand Water, Vereeniging, South Africa, for analyses, Medical Research Council for academic support and SNOWS consortium for support in academic writing. 


\section{REFERENCES}

[1] Ahmed, M.S., Hiller, S., Luckes, B. (2008): Microcystis aeruginosa Bloom and the Occurrence of Microcystins (Heptapeptides Hepototoxins) From an Aquaculture Pond in Gazipur. - Turkish Journal of Fisheries and Aquatic Sciences 8: 37-41.

[2] Azevedo, S.M.F.O., Carmichael, W., Jochimsen, E.M., Rinehart, K.L., Lau, S., Shaw, G.R. Eaglesham, G.K. (2002): Human intoxication by microcystins during renal dialysis treatment in Caruaru-Brazil. - Journal of Toxicology 181-182: 441-446.

[3] Azevedo, S.M.F.O., Chernoff, N., Falconer, I.R., Gage, M., Hilborn, E.D., Hooth, M.J., Jensen, K., Macphail, R., Rogers, E., Shaw, G.R. Stewart, I. (2008): Cyanobacteria Harmful Algal blooms: Chapter 26: Human health effects working group report. - United States Environmental Protection Agency.

[4] Backer, L.C., Carmichael, W., Kirkpatrick, B., Williams, C., Irvin, M., Johnson, T.B., Nierenberg, K., Hill, V.R., Keiszak, S.M. Cheng, Y. (2008): Recreational Exposure to Low Concentrations of Microcystins during an algal bloom in a small lake. - Marine Drug 6: 389-406.

[5] Brookes, J.D., Daly, R., Regel, R.H., Burch, M., HO, L., Newcombe, G., et al. (2008): Reservoir management strategies for control and degradation of algal toxins. Denver, Colorado, USA. - American Water Works Association Research Foundation.

[6] Burch, J.D., Thomas, K.E. (1998): Water disinfection for developing countries and potential for solar thermal pasteurization. - Solar Energy 64: 87-97.

[7] Chaturvedi, P., Kumar-Agrawal, M. Nath-Bagchi, S. (2015): Microcystin-producing and non-producing cyanobacterial blooms collected from the Central India habour potentially pathogenic Vibrio cholera. - Ecotoxicology Environmental Safety 115: 67-74.

[8] Chen, J., Xie, P., Li, L., Xu, J. (2009): First Identification of the Hepatoxic Microcystins in the Serum of a Chronically Exposed Human Population Together with Indication of Hepatocellular Damage. - Toxicological Sciences 108(1): 81-89.

[9] Chorus, I., Bartram, J. (Eds.)(1999): Toxic Cyanobacteria in Water: A Guide to Their Public Health Consequences, Monitoring and Management. - St Edmundsbury Press, Bury St Edmunds, Suffolk. First pblished by E \& FN Spon.

[10] Codd, G.A., Morrison, L.F., Metcalf, J.S. (2005): Cyanobacterial toxins: risk management and health protection. - Toxicology \& Applied. Pharmacology 203: 264272.

[11] Daly, R.I., Ho, L. Brookes, J.D. (2007): Effect of Chlorination on Microcystis aeruginosa Cell integrity and subsequent Microcystin release and degradation. - Environmental Science and Technology 41: 4447-4453.

[12] De Figueiredo, D., Azeiteiro, U., Esteves, S., Gonçalves, F., Pereira, M. (2004): Microcystin-producing blooms--a serious global public health issue* 1. - Ecotoxicology and Environmental Safety 59(2): 151-163.

[13] Department of Water Affair and Forestry (DWAF). (1996): South African Water Quality Guidelines. 2nd Edition. Volume 5., Agricultural water use: Livestock watering. - The Government Printer, Pretoria

[14] Ding, X.S., Li, X.Y., Duan, H.Y., Chung, I.K. Lee, J.A. (2006): Toxic effects of Microcystis cell extracts on the reproductive system of male mice. - Toxicon 48: 973-979.

[15] Duy, T.N., Lam, P.K.S., Shaw, G.R., Connell D.W. (2000): Toxicology and risk assessment of freshwater cyanobacterial (blue-green algal) toxins in water. - Reviews of Environmental Contamination \& Toxicology 163: 113-185.

[16] Falconer, I.R. (2005): Cyanobacterial toxins of drinking water supplies: cylindrospermopsins and microcystins. - Boca Raton: CRC Press p. 279.

[17] Fawell, J.K., James, H.A., James. H.A. (1994): Toxins from blue-green algae: Toxicological assessment of Microcystin-LR and a method for its determination in water. - Water Research Centre, Medenham, England Report number FR 0359/2DoE 3358/2. 
[18] Fosso-Kankeu, E., Jagals, P., Du Preez, H. (2008): Exposure of rural households to toxic cyanobacteria in container stored water. - Water SA 34: 631-636.

[19] Funari, E., Testai, E. (2008): Human health risk assessment related to cyanotoxins exposure. - Critical Reviews in Toxicology 38: 97-125.

[20] Gélinas, M., Fortier, M., Lajeunesse, A., Fournier, M., Gagnon, C., Barnabé, S., Gagné, F. (2014): Responses of freshwater mussel (Elliptio complanata) hemocytes exposed in vitro to crude extracts of Microcystis aeruginosa and Lyngbya wollei. - Ecotoxicology 23: 260-266.

[21] Gundry, S., Wright, J., Conroy, R. (2004): A systematic review of the health outcomes related to household water quality in developing countries. - Journal of Water and health 2 (1): 1-13.

[22] Hiscock, K.M., Grischek, T. (2002): Attenuation of groundwater pollution by bank filtration. - Journal of Hydrology 266: 139-144.

[23] Hoffman, J.R.H. (1976): Removal of Microcystins toxins in water purification processes. - Water SA 2: 58-60.

[24] Humpage, A.R., Falconer, I.R. (2003): Oral toxicity of the cyanobacterial toxin cylindrospermopsin in male Swiss albino mice: Determination of no observed adverse effect level for deriving a drinking water guideline value. - Environmental Toxicology 18: 94-103.

[25] Ito, E., Kondo, F., Terao, K. Harada, K.L. (1997): Neoplastic nodular formation in mouse liver induced by repeated intraperitoneal injections of microcystin-LR. - Toxicon 55: 1453-1457

[26] Jagals, P. (2006): Does improved access to water supply by rural households enhance the concept of safe-water at the point of use? A case study from deep rural South Africa. Water Science and Technology 54: 9-16.

[27] Jochimsen, E.M., Carmichael, W.W., An, J., Cardo, D.M., Cookson, S.T., Holmes, C.E.M., et al., (1998): Liver failure and death after exposure to Microcystins at a Hemodialysis Center in Brazil. - New England Journal of Medicine 338(13): 873-878.

[28] Masango, M.G., Myburgh, J.G., Labuschagne, L., Govender, D., Bengis, R.G., Naicker, D. (2010): Assessment of Microcystins bloom toxicity associated with wildlife mortality in the Kruger National Park, South Africa. - Journal of Wildlife Diseases 46: 95-102.

[29] Moreno, I.M., Maraver, J., Aguete, E.C., Leao, M., Gago-Martinez, A. Camean, M. (2004): Decomposition of Microcystin LR, Microcystin-RR and Microcystin-YR in water submitted to in Vitro Dissolution Tests. - Journal of Agriculture, Food and Chemistry 52: 5933-5938.

[30] Muyodi, F.J., Hecky, R.E., Kitamirike, J.M. Odong, R. (2009): Trends in health risks from water-related diseases and cyanotoxins in Ugandan portion of Lake Victoria basin. Lakes \& Reservoirs: Research \& Management 14: 247-257.

[31] Neilan, B.A., Pearson, L.A., Muenchhoff, J., Moffitt, M.C., Dittmann, E. (2013): Environmental conditions that influence toxin biosynthesis in cyanobacteria. Environmental microbiology 15: 1239-1253.

[32] Nicholson, B.C., Rositano, J., Burch, M.D. (1994): Destruction of cyanobacterial peptide hepatotoxins by chlorine and chloramine. - Water Research 28: 1297-1303.

[33] Nobre, A.C.L., Jorge, M.C.M., Menezes, D.B., Fonteles, M.C. Monteiro, H.A.S. (1999): Effect of microcystin-LR in isolated perfused rat kidney. - Brazilian Journal of Medical and Biological Research 32: 985-988.

[34] Oberholster, P., Ashton, P.J. (2008): State of the nation report: An overview of the current status of water quality and eutrophication in South African Rivers and Reservoirs.

[35] Oberholster, P.J., Botha, A., Cloete, T.E. (2005): An overview of toxic freshwater cyanobacteria in South Africa with special reference to risk, impact and detection by molecular marker tools. - Biochemistry Nigerian Society for Experimental Biology 17(2): $57-71$. 
[36] Pawlik-Skowronska, B., Pirszel, J., Kornijow, R. (2008): Spatial and temporal variation in microcystin concentrations during perennial bloom of Planktothrox agardhii in a hypertrophic lake. Annales de Limnologie - Intentional Journal of Limnology 44(2): 145150.

[37] Pilotto, L., Douglas, R., Burch, M., Cameraon, S., Beers, M., Rouch, G., Robinson, P., Kirk, M., Cowie, C., Hardiman, S., Moore, C. Attewell, R. (1997): Health effects of exposure to cyanobacteria (blue-green algae) during recreational water-related activities. Australia and New Zealand Journal of Public Health 21: 562-566.

[38] Sánchez-Bayo, F., Van Den Brink, P.J., Mann R.M. (2011): Ecological Impacts of Toxic Chemicals. - Bentham Science Publishers Ltd.

[39] South African National Standard 241-1. (2011): Drinking water standard. By SABS Standard Division, Pretoria, ISBN 978-0-626-26115-3 p 1-46.

[40] Tsuji, K., Watanuki, T., Kondo, F., Watanabe, M.F., Nakazawa, H., Suzuki, M., et al. (1997): Stability of Microcystins from cyanobacteria-iv. Effect of chlorination on decomposition. - Toxicon 35(7) 7: 1033-1041.

[41] Turner, P.C., Gammie, A.J., Hollinrake, K., Codd, G.A. (1990): Pneumonia associated with contact with cyanobacteria. - British Medical Journal 300: 1440-1441.

[42] U.S. Environmental Protection Agency. (2005): Guidelines for Carcinogen Risk Assessment. Risk Assessement Forum U.S. - Environmental Protection Agency, Washington, DC. March 2005, EPA/630/P-03/001B.

[43] Willen, E., Ahlgren, G., Tilahun, Spoof, L., Neffling, M.R., Meriluoto, J. (2011): Cyanotoxin production in seven Ethiopian Rift Valley Lakes, G, Riina M. - Inland Water 1: 8-91.

[44] World Health Organization. (1998): Cyanobacterial toxins: Microcystin-LR in Drinkingwater, Guidelines for drinking-water quality, 2nd ed. Addendum to Vol. 2. Health criteria and other supporting information. - World Health Organization, Geneva, 1998.

[45] World Health Organization. (2006): Guidelines for Drinking-water Quality: First addendum to third edition. - World Health Organization, Geneva.

[46] Zong, W., Sun, F., Pei, H., Hu, W., Pei, R. (2015): Microcystin-associated disinfection by-products: The real and non-negligible risk to drinking water subject to chlorination. Chemical Engineering Journal 279: 498-506. 